\title{
Decolonial Theory in East Asia? Outlining a Shared Paradigm of Epistemologies of the South
}

Teoria descolonial na Ásia Oriental? Delineando um paradigma partilhado das epistemologias do Sul

La théorie décoloniale en Asie de l'Est ? Décrivant un paradigme partagé des épistémologies du Sud

\section{Jordi Serrano-Muñoz}

\section{OpenEdition}

\section{Journals}

Electronic version

URL: https://journals.openedition.org/rccs/11430

DOI: $10.4000 /$ rccs. 11430

ISSN: 2182-7435

\section{Publisher}

Centro de Estudos Sociais da Universidade de Coimbra

Printed version

Date of publication: 1 May 2021

Number of pages: 5-26

ISSN: 0254-1106

\section{ELECTRONIC REFERENCE}

Jordi Serrano-Muñoz, "Decolonial Theory in East Asia? Outlining a Shared Paradigm of Epistemologies of the South", Revista Crítica de Ciências Sociais [Online], 124 | 2021, Online since 26 May 2021, connection on 31 May 2021. URL: http:// journals.openedition.org/rccs/11430 ; DOI: https://doi.org/10.4000/rccs.11430 


\section{Decolonial Theory in East Asia? Outlining a Shared Paradigm of Epistemologies of the South*}

This paper explores the challenges and potentialities of establishing a shared paradigm of transformative knowledge based on the dialogue between East Asian experiences and the rest of the global South, particularly Latin America. It gathers and organizes a general overview of significant attempts of framing East Asian struggles within resistances against Western hegemonic epistemological impositions. It makes the case for seeking shared links and critical differences that can help to incorporate East Asian experiences within the paradigm of epistemologies of the South. This study also problematizes the articulation of a propositional methodology of comparison that could nurture the production of local, decolonial approaches and foster the exchange of practices and knowledges from and to East Asia.

Keywords: Asia; colonialism; epistemological decolonization; global South; theory of knowledge.

Silvia Rivera Cusicanqui, in her article "Ch'ixinakax utxiwa: A Reflection on the Practices and Discourses of Decolonization”, exposes the challenges and potentialities of raising the status of indigenous epistemologies to openly defy contemporary global hegemony. She closes the piece with these words:

\footnotetext{
"I would like to express my most sincere gratitude for the tremendous help I received during the production of this article. I wish to credit the brilliant insight from the anonymous peer-reviewers whose suggestions regarding ongoing debates addressing the connection between epistemic and social justices, among other relevant comments, led me to articulate a much better work. I would also like to commend the great editorial work of the Revista Crítica de Ciências Sociais, whose patient back and forth proves that attention to detail in the spirit of horizontal collaboration is the key to a better system of knowledge production. Finally, I also want to recognize the friends, colleagues, and even strangers with whom I have shared part of this ongoing research in public and provided me with feedback, particularly during the Western Conference of the Association for Asian Studies - WCAAS 2019 in Mexico City and at the seminars organized by the South Training Action Network of Decoloniality research group at the University of Granada - STAND-UGR, Spain.
} 
The challenge of this new autonomy is in constructing South-South links that will allow us to break the baseless pyramids of the politics and academies of the North and that will enable us to make our own science, in a dialogue among ourselves and with the sciences from our neighboring countries, by arming our bonds with theoretical currents of Asia and Africa - that is, to confront the hegemonic projects of the North with the renewed strength of our ancestral convictions. (Rivera Cusicanqui, 2012: 107)

A text originally written in Spanish, she goes on to frame this struggle in the fight against the oppressive structures of modernity and colonialism. Rivera Cusicanqui focuses her criticism in this and other works beyond the most recognizable agents of oppression, that is, powers and players of the global North, which are however also accounted for. She devotes considerable effort to critically reviewing those intellectuals in the South who have portrayed themselves as counter-hegemonic - decolonial, postcolonial, Marxist, or under any other label - and assails their attempts for either falling too short, employing a misguided strategy, or even for being counter-productive in terms of their stated objectives. Rivera Cusicanqui builds her arguments for the empowerment of indigenous epistemologies based on her knowledge and understanding of Latin America's history of contesting these structures of colonial oppression. She weaves her thesis with a call for a trans-regional, trans-territorial, transcultural "South-South link" that would include experiences not only from America but also from Asia and Africa.

She is not alone in this regard. Many other scholars and thinkers who work on the same or similar decolonial intellectual and activist struggles, both inside and outside Latin America, share the same hope for a more global exchange of knowledge. Highly commendable reactions to this appeal have arisen from Africa, the Middle East, and South Asia, especially India. In contrast, exchanges with East Asia on this issue reflect a somewhat timid response. Calls to incorporate decolonial ideas in the understanding of East Asian experiences, from this vantage point, do not seem to go much beyond statements expressing resolutions and will. Rather than simply manifesting the desire - and one could even argue the need - for a cross-border strategy, it has become clear that we must go further than acknowledging the need for a bridge and must start making plans to set the first stones of the structure.

This article explores the limits, challenges, and opportunities for the exchange of transformative knowledge when it comes to crossing borders throughout the global South. It offers a panoramic review of several 
significant attempts that have understood experiences happening in East Asia related to a system of epistemological oppressions shared by other communities within the global South. In some instances, these efforts have engaged with decolonial and postcolonial concepts as developed in Latin America, Africa, or South Asia, drawing from parallelisms or useful differences to build their cases. In other instances, these exercises develop their particular models of criticism against epistemic oppression that could be nevertheless put into dialogue with work being done in other parts of the global South.

These attempts depart from a position of struggle against capitalism, patriarchy, and colonialism in their different shapes and manifestations. As such, I defend the promise of Boaventura de Sousa Santos' "epistemologies of the South" as a term that can encompass them as sharing a common ground of diagnosis, operations, and objective: epistemic justice leads to social justice. However, despite Santos' global aspiration to his conceptualization of the term, the socio-historical context of the so-called East Asian region has been left out of his analyses. ${ }^{1}$ As the authors and works presented in this paper suggest, a decolonial (or decolonial-like) approach to the historical relationships between and within China, Japan, and Korea (just to mention the three most important contemporary states in that artificially delineated region) is not only useful for a better understanding of their idiosyncrasies, but it can also provide potentially beneficial points of reference for the exchange of non-Eurocentric knowledge across a richer cohort of communities.

\section{East Asia and the Epistemologies of the South}

The most potent weapon in the hands of the oppressor is the mind of the oppressed.

Steve BiKo (1994: 8)

Epistemologies of the South "concern the production and validation of knowledges anchored in the experiences of resistance of all those social groups that have systematically suffered injustice, oppression, and destruction caused by capitalism, colonialism, and patriarchy" (Santos, 2018b: 1). They do not necessarily correspond to a geographic South, but rather encompass the spirit of wishing to disrupt the current order of power,

\footnotetext{
${ }^{1}$ Boaventura de Sousa Santos' latest book in English on epistemologies of the South, The End of the Cognitive Empire, includes a thorough state of the art review on decolonial theory by regions; however, it does not include any specific mention of efforts in East Asia.
} 
both material and epistemological, as it has been imposed and naturalized as a monopoly by the West. The objective of these epistemologies is simultaneously not the replacement of the North as hegemon. They are aimed at ending the hierarchical distribution of knowledge and being. In Santos' words, "the question is not the erasing of the differences between North and South, but the erasing of the power hierarchies that inhabit them" (2018a: 35). ${ }^{2}$ The goal of working for and with epistemologies of the South is the integration of the axiom that there cannot be social justice without cognitive justice: "the only centrality acknowledged by the epistemologies of the South has no center: it is the centrality of the struggles against capitalist, colonial, and patriarchal domination wherever they may take place" (Santos, 2018b: 117).

Decolonial theory builds its criticism by challenging the way the project of modernity has been understood and considering it complicit with the current system of global hegemony. It establishes a difference between historical colonization and what Aníbal Quijano coined as "coloniality". Putting it in the simplest terms, colonization is the process of possessing a power that politically, economically, culturally, and militarily subjugates another. Coloniality is the term that we can use to refer to the process that allows the establishment, reproduction, and perpetuation of these structures of oppression. Decoloniality is, as Walter Mignolo (2010: 10) puts it, "the invisible and constitutive part of modernity". It is the fabric woven to legitimize both the agents and the means of exerting power for the last 500 years. The system of coloniality has configured a world that naturalizes and legitimizes the hegemonic disposition associated with the project of modernity by acting simultaneously in three dimensions. These are the "coloniality of being" (how we identify and define ourselves and the rest); the "coloniality of knowing" (what is valid and what is invalid knowledge); and the "coloniality of mind" (how we make sense of the world and its circumstances). Quijano calls the combination of these three dimensions "the coloniality of power".

Maria Lugones adds the dimension of race and gender to Quijano's work. She argues that the paradigm of coloniality cannot be sourced only to a critical analysis of modernity and must include how dynamics of genderization, sexualization, and racialization have shaped individuals and communities alike within a unique matrix of oppression. These categories, according to Lugones, must be acknowledged within what she calls a coloniality of gender: gender struggles are decolonial struggles

${ }^{2}$ All quotes from languages other than English in the present article are translated by the author. 
because they cannot be broken apart without becoming "an empty category" (Lugones, 2010: 745). Similarly, Ramón Grosfoguel expanded on Quijano's coloniality of power to add Kontopoulos' idea of "heterarchy". These are multiple horizontal hierarchies that include the social imaginary and which explain how global power structures were built and are being maintained to this day (Grosfoguel, 2006: 172).

Rivera Cusicanqui has developed her work parallel to - and even in critical confrontation with - decolonial thinkers. In terms of her analytical exploration of the causes and circumstances that require a decolonial turn, she shares with Quijano, Mignolo, Grosfoguel, and other like-minded individuals the same commitment to a staunch denunciation of the systems of power and the construction of solutions alternative to the project of modernity. Her points of disagreement, however, are found in some of the means and methods in which decolonial studies have structured its mechanisms of resistance, mainly those entrenched in academic institutions. Despite their differences, Rivera Cusicanqui and other critics - Boaventura de Sousa Santos, for instance, considers unnecessary the use of the term "coloniality" at the same time he concurs with its diagnostic (2018b: 110) - share commonality with other decolonial thinkers in their appeal for a more global understanding of these systems of epistemic and ontological oppression. That is, the promotion of the aforementioned cross-border South-South strategies that could break the mental and material chains of the North.

A concern of intellectuals from the global South throughout the twentieth century has been the aspiration to build a bridge for the dissemination of knowledge and strategies across Asia, Latin America, and Africa meant to bypass the direct mediation of the West. Many of these thinkers were inspired to a model of international socialism or strove to emulate it. It has been a complicated and highly sensitive task - and to my mind, remains so - for decolonial studies to provide the proper and necessary criticism to Marxism as an emancipating and transformative paradigm for the global South, while at the same time honoring its contributions to a system of solidarity and interconnectedness. From a position of cognitive justice, the shortcomings of Marxism involve its inextricably Western epistemological matrix and its traditionally doctrinal tendencies. The analysis and solutions proposed within traditional Marxist socialist thought also operate with the same terms and logic of the project of modernity and have little regard for different (e.g., indigenous) epistemological systems. Rivera Cusicanqui herself has devoted part of her work to tracing how Latin-American transformative and revolutionary impulses (she studies the Bolivian 
case in particular) have been co-opted and entrapped in the "straight-jacket of national structures to the left-wing in a way that could not consider any epistemological alternative" (Rivera Cusicanqui, 2018: 21). Mignolo (2010: 41) puts it simply when he says that the project of ending the coloniality of power "is difficult to conceive from a Marxist perspective, because Marxism offers a different content but not a separate logic". Decolonial thinking offers a follow-up to Marxist aspirations that is not an attack on its propositions and critical aim but rather an enterprise that exposes its unsuitability to build proper solutions.

This struggle becomes one of the main concerns for David Haekwon Kim in his work on Peruvian writer José Mariátegui (Kim, 2015). Kim wishes to rescue and frame Mariátegui as a pioneer of decolonial thought who, already during the first quarter of the twentieth century, sought to create a dialogue between ideas about Asia and China and Latin America's scramble against oppression. One of the ways Mariátegui suggested this could be achieved was by adopting an interpretation of socialism in Peru. The challenge for Kim is then to untangle the potentially game-changing qualities of Mariátegui's decolonial readings and approaches from the Eurocentric fabrics of his thoughts. This question has been in turn one of the central conundrums of decolonial practice. Thinking in Eurocentric terms perpetuates a colonial hierarchy of knowledge. It also confers the Western disposition of scales of being with authority to define the place of peoples within the ranks of power. Eurocentrism is incapable of producing effective self-criticism if it does not leave behind the shackles of its exclusive epistemological paradigm. At the same time, criticizing Eurocentric thought excluding Western theoretical traditions also cannot be considered adequate. It alienates the subject to be changed and perpetuates Otherness without moving towards horizontality. We must embrace, therefore, the paradox of having to engage with Western conceptual frameworks to challenge and tear down their oppressive and hegemonic structures. This tension and contradiction need to be paired with an open engagement with alternative epistemologies on equal terms. Non-Western thoughts and experiences must be considered and their mixing encouraged.

Kim brilliantly exposes these conflicts and offers a way to operate within them. He journeys on a reflection about these frictions to eventually produce an analysis of Mariátegui's oeuvre. He sheds light on how to effectively read and comment on his contributions to comparative philosophy and political thought at a safe distance from Eurocentrism. At the same time, by choosing to reclaim Mariátegui's figure and work, 
Kim is contributing to stimulating decolonial paths between Chinese and Latin-American traditions of thought. He is acting in the same spirit of bonding and coadjuvancy that Mariátegui suggested by looking for shared motives of inspiration and incentive between Confucianism and Inca thought.

The scarcity of bridges and connections between these different non-Western epistemologies is better understood when we approach it as the desired outcome of coloniality. It is indicative of a paradigm that has positioned people and knowledge in a hierarchical position of inferiority to justify Western power as the legitimate global hegemon. The process of naturalizing subalternity implies assuming a scale of validity and worth that is dictated by the needs and logic of the project of modernity. Santos (2007) uses the term "abyssal line" to talk about an imaginary border created by agents of power that helps us visualize the division of people and knowledge as either "legitimate" or "invalid". Everyone and everything that is above the abyssal line is recognized by agents of power as valid, as justifiable, and therefore, as existing. Included above the abyssal line are identities (for instance, white heterosexual male), practices (neoliberal policies), knowledges (Western philosophy), and epistemologies (the Enlightenment-led project of modernity). In opposition to this, everything that falls below the abyssal line is invalid, it is invisible, and it represents the oppressed in any dimension. We could include below the abyssal line, for instance, Indigenous knowledge, the struggles for land, resources, cultural rights of underrepresented communities, or racially or gender-based political disenfranchisement.

Tani Barlow (2012) highlights how during the 1990s debates over whether the countries of East Asia were colonies or not was too often based on a narrow and Eurocentric understanding of colonialism. She started working on the term "colonial modernity" to break with a sequential understanding of modernity and colonialism and place them as occurring together in a relationship of mutual co-dependence with global capitalism. Modernization, in her understanding, needs to be approached at the same time as a multileveled, multinational endeavor that is neither static nor particular. The term was picked up by other authors such as Hyunjung Lee and Younghan Cho, who claimed the relevance of colonial modernity as a framework that can better address the needs and circumstances of East Asian communities. As they point out:

The iterating role of Western or American centrism in East Asia compels us to approach the region's coloniality in a way that reaches beyond the notion or even 
the historical reality of territorial occupations. Instead, East Asia's coloniality must be considered on symbolic, psychological, and institutional levels. (Lee and Cho, 2012: 606)

In the end, they too call for approaching East Asia, just like Latin America, as the oppressed periphery that makes "the modern/colonial world visible" (ibidem: 609). To study it properly, therefore, it needs "a viable alternative conceptual framework [...] on equal terms with existing theories, by virtue of the accumulated cases, knowledge and conceptual terms specific to this region" (ibidem: 610). Barlow (2012: 635) also argues quite convincingly that it has been the colonialist fixation with land and space which has shaped an epistemology that is more concerned with regions, territories, borders, and nations. Time - and particularly the abandonment of linear, histori$\mathrm{cal}$, and providential progress - reveals the clutches of this system, a call that also resonates with Rivera Cusicanqui's endorsement of the Aymara concept of Pachakuti and the Indigenous wariness of linear history (Rivera Cusicanqui, 2012: 96).

One of the main hindrances to the free exchange of knowledge across the global South is the colonial configuration of modern institutionalized knowledge. Academia, the press, and other models of interest to the public intellectual reflect the prowess of coloniality in East Asia and Latin America. These are shaped to accommodate a Eurocentric understanding of legitimate wisdom that reproduces unequal and hierarchic structures. By way of example, Chih-Ming Wang (2012) in his piece "Geopolitics of Literature" explores how the colonial intertwining in the construction of literary canons in China and Taiwan, both on foreign and "national" literatures, do not question but rather reify current paradigms of power. He denounces how the advancement of critical postcolonial studies in those departments devoted to exclusively analyzing the matter has not necessarily trickled down to other disciplines. Rather, it has allowed the field of literary studies to remain comfortably anchored as a discipline dedicated to the perpetuation of two sides, East and West, which shout at but never meet because their distance is based on an unequal distribution of power.

Wang (ibidem) tracks down the entanglement of these circumstances to the creation of the discipline of Comparative Literature in early twentieth-century China. The idea of national literature in China as it came to be - and continued to be, in parallel in Taiwan afterwards - emerged historically as an import from contact with Western powers. The Chinese term meaning "foreign literature", waiguo wenxue, is narrowly used in practice 
to refer basically to Euro-American literary traditions. Wang interprets the narrowness of waiguo wenxue to include only Western tradition as another reflection of coloniality. It perpetuates the impossible goal of having to imitate the so-called "Western spirit" by creating a national one that would compare and give tools for linearly catching up with them. It meant the artificial revival of "Classical Chinese" in a fashion that did not respond to the needs or wishes of the community but instead to the demands of the project of modernity. Comparative Literature needs to take into account the structural and institutional implications of the discipline and its medium to avoid risking the naturalization of unequal relationships.

We must distinguish between the mere nurturing of local epistemological orders, inscribed as regional and regionalized ways of conducting research and exchanging knowledge, from the necessary turn towards a meeting of methodologies. It is not only about recognizing the existence of other ways of knowing and doing. We must also foster a reciprocal exchange that can naturalize and integrate the employment of concepts previously identified as indigenous in exogenous scenarios. In her work Connected Sociologies, Gurminder Bhambra (2014) argues for the need to examine the intersection of historical processes and connections as the juncture that can produce a horizontal exchange freer from Eurocentric epitomes. In her view, by directing attention toward these junctions, she hopes "to open up space to think about sociology differently through an acknowledgment of other histories and experiences as well as to enable a reconsideration of the relations between disciplines", for "there is no connection where there is no reconstruction; and no understanding remains unchanged by connection" (ibidem: 3-5).

The distribution of power within structures of oppression must be understood as a process happening at different levels: from international, to regional, to national, to local, epistemic and material persecution based on hierarchies of knowing and being can also be traced within the so-called East Asian region. Asian identity and Asian intellectual traditions have been alternized, regionalized, deprived of autonomous initiative, and ultimately subordinated to the engendering gaze of the West. For modern Eurocentric hegemony, they have been placed in many circumstances below the abyssal line. At the same time, however, Chinese, Korean, and Japanese elites also subalternate minorities and their epistemological orders.

The work of Chiara Olivieri is focused on applying a decolonial approach to untangle the way Islamic communities have been constructed in the Chinese imaginary. Olivieri (2016) denounces how Chinese minorities and 
repressed groups suffer from the same apparatus of subalternization at the hands of the central government. She argues that the key aspect that ensures "acceptability" and prevents them from being placed below the Chinese abyssal line is the proximity to one's being, knowing, or learning about Islamic communities in China with respect to Han power. Religious plurality is accepted only as long as it does not challenge the ultimate legitimacy of Han rule in material and epistemological ways. Her main argument is that power-bound Chinese approaches to Islam reproduce the same scheme of global colonial power relationships.

Olivieri follows the historical development of Sino-Muslim thought to reveal how the existence of Islam within the Chinese sociopolitical order has been subordinated to the integration of their doctrinal principles to the larger Han epistemological order. This logic included the integration of Imams as Confucian literati and the consideration of Islam as a Dao, next to the rest, testing the flexibility and tolerance to the precepts of Tawhid. Those Islamic communities within China that fail short of integrating this epistemological disposition - and the contemporary dogma of national unity promoted by the government - are within this system "legitimately" persecuted. The justification for this discrimination is based on the grounds of state security and the terrorist threat, with the added particularity of being systematic instead of targeting and singling out dissent. She drafts the comparison to illustrate her point between the Hui and the Uighur community. While the Hui are mildly tolerated by the Chinese establishment, the Uighur's resistance to wholeheartedly assimilate to the epistemological hierarchy of Han power legitimates the material, military, and cultural repression acted upon them:

The traditions and the Uighur's own identity are therefore instrumentally employed by the State. They become a "primitive" and "attractive" folkloric element with which they belittle - and thus dominate - the people recognized as such. The "periphery" is, in this scheme, the world that needs to be "sinicized" (that is, "hanicized"). It is unable to civilize or develop by its own means, hence justifying the intervention of the State. (Olivieri, 2016: 72)

In her book Liminality of the Japanese Empire, Hiroko Matsuda (2018) produces a study on the different strata of contextual oppression existing during Japan's colonial project and which can arguably be followed to contemporary times. She focuses mainly on the permeability and subversion of the categories "colonizer/colonized" when discussing the status of peoples from Taiwan and Okinawa against mainland Japan and each other. 
Similarly, Yolanda Muñoz González (2008) has done work on the way Ainu communities from Hokkaidō, in Northen Japan, have been historically subalternized by non-racialized Japanese. This process of differentiation was institutionalized during the nineteenth century and legitimized other agents in attacking the Ainu. Communities that were subalternized in other parts of Japan, like poor peasants, once they were mobilized by the State to work in Hokkaidō, suddenly saw their social status elevated based on an alleged superiority over the Ainu.

The way the Japanese state and its constitutive agents took in and adapted a logic of oppression is one of Hidefumi Nishiyama's research topics. In his piece "Towards a Genealogy of Biopolitics" he explores how biometric technologies were first imported from the West during the nineteenth and twentieth centuries and then converted to meet the needs of Japan's hegemonic national and imperial rule: "to put it another way, what was translated was not particular forms of knowledge - for example, the European taxonomy of race, the discourse of the "White man's burden", and so on - but rather the very condition of racial knowledge in which the biological-racist discourse beyond Eurocentrism became possible" (Nishiyama, 2015: 342). As we have seen, Eurocentric critical thinking is not enough and can be counter-productive in the struggle to design better epistemologies of the South. We must purposely include the nurturing of our ecosystem of knowledges to and from the global South. It should include an open dialogue between agents that experience or that can identify exclusion across all the affected territories and at every level of incidence. Knowledges from East Asia and Latin America, for instance, have suffered similarly from having been disparaged by Western authority. Non-Western epistemologies have been channeled as religious or mystic, and their conditions, secluded from the imposed rationality, needed to carry on the project of modernity and thus were cast away as eternally peripheral. That is, they have been underrated and undersold for not being "true knowledge". Any community that adopts these epistemological frameworks under the logic of the current hegemonic order is condemned to remain subdued. Empowering the struggles of a community needs to coincide with the empowering of their epistemological traditions.

Instead of looking to modernity's fetish of living out the nostalgia of a static and harmless historical past, we must instead harness the power of that which has not been lost, despite certain appearances, in the effort to build a future that can foil the damage done, this time incorporating the knowledge acquired through its effects. In the context of East Asia, this can go from rekindling the power within indigenous epistemologies 
to reformulating ways of approaching foundational traditions such as Confucianism, Taoism, or Buddhism. This task must go against the patronizing gaze of the West. It must also confront the prejudices of particular national and regional elites that have bought into and reproduced coloniality of knowledge's belief that these epistemologies are invalid as they do not fit the project of modernity.

This denunciation rings close, for instance, to Leigh Kathryn Jenco's invitation to re-conceptualize cross-cultural exchange, taking into account alternative, local traditions such as new insights into Confucianism. In her work "What Does Heaven Even Say?" Jenco (2007) designs a traditional Chinese method of exegesis based on Kang Youwei and Wang Yangming's texts. She is motivated by the need to defeat the irony of having to apply Western approaches to cross-cultural work. She also seems to propose that we remodel our epistemological understanding to acknowledge its colonial institutional embedding, that we accept its limitations and shortcomings, and embrace its contradictions.

Jenco builds her reflection on these challenges from the work of these two influential yet relatively controversial Confucian intellectuals, who shared a reformist spirit despite the four centuries that separate them. Both Wang Yangming and Kang Youwei wished to break the chains of formal text-oriented conventions in literacy to "adopt hermeneutic stances that privilege human relationships, action, and the understandings these practices convey, rather than the abstracted conversations or speech-based interventions of much contemporary cross-cultural theory" (ibidem: 751). Wang Yangming fought discreetly against the principle of textual and canonical authority to favor individual interpretation and consideration. This stance debunks any prepositions of Confucianism as inherently static and conservative, to free and open up our relationship with texts and traditions based on individual judgment. Jenco then explores Kang Youwei's social and moral commitment when approaching classics. Instead of subjective sensitivity, Kang believed texts to be a source for inspiration on a community's ongoing struggles. Jenco combines Kang and Wang's understanding of an individual's relationship with classics to expose the myth of textual invariability as a fixed source of meaning. It needs to reach out to these alternative epistemologies to build together a cross-cultural panorama of diverse methodologies that can adequately address the equally diverse multiplicity of experiences.

Xiaoying Qi develops another remarkable attempt of putting these ideas of cross-methodological validity into practice. She has looked at how research done on social movements in China and from China overlooks 
the relevance of guanxi, or the system of interpersonal obligations that weave together social interaction in Chinese societies. Qi (2017) explores how guanxi plays a key role in the contextual development of social movements, how it is utilized by activists to build their networks and by the State to suppress them. She points out that one of the main reasons guanxi has been ignored in previous scholarship on the matter is because the field has been theorized mainly from the global North. Researching Chinese social movements using a term from Chinese sociology becomes, under this light, an unexpected act of epistemic insurrection. Moreover, Qi believes that the concept of guanxi has a potentially beneficial quality, and it can help us "refine and expand the conceptualisation of social movements and develop social movement theory to understand collective action and protest not only in contemporary China but in general terms" (ibidem: 123).

Lisa Yoneyama (2017) builds a compelling case for the revisiting of the concept of "Transpacific". She defends this idea as an emboldening critical methodology if we decolonize it from being material and epistemological space, colonially occupied nowadays mainly by the United States (US). Yoneyama envisions it as a framework to study "alternatives to transwar, interimperial, Cold War formations" (ibidem: 472). She outlines the genealogy behind the development of the Pacific as a conceptual and geopolitical arena. In her account, the US used its victory over Japan and the liberation of its former colonies from its imperial subjugation to shape a new paradigm that could substitute Japan as the hegemon in the Pacific without its being perceived as such.

In this new scenario, the US has justified its patronage and military vigilance over the idea of an ever-looming enemy, a challenger to its position disguised as a menace to the region. US domination in the Pacific has also contributed to the erasing of indigenous material and epistemological rights. The United States' overseas economic and military agenda entails the elimination of Indigenous resistance by rendering their ways of being and doing invisible. Yoneyama refers to the work of Setsu Shigematsu and Keith Camacho to raise the point of "the ways in which 'the Pacific' has long been treated 'as an open frontier to be crossed, domesticated, occupied, and settled'" (ibidem: 477), which harkens to Frederick Turner's popularized theory of the US frontier mentality and expansion.

The Transpacific can be an opportunity to activate and re-engage the conception of resistances in Latin America and Asia as having a common systemic structure of oppression, with the US also as a familiar destabilizing power. This connection has also been identified as the grounding 
principle for Joseph Roach's concept of circumoceanism: "the collective and institutional memories that connect the distant oceanic networks of the slave trade that constituted the cultures of modernity" (Lee, 2018: 10). Ana Paulina Lee explores the usefulness of this concept when approaching the East Asian diaspora in Latin America and the Caribbean. She designs a thorough study of the history and role of Chinese and Japanese communities in Brazil, particularly at the end of the nineteenth century and later throughout the twentieth century.

Lee's main argument in her book Mandarin Chinese is the denouncing of "how processes of racialization overlap in synchronous states of modernity/coloniality, in the making of the modern world that was inseparable from the making of the colonial order" (ibidem: 11). She argues that racism should be understood beyond the oppression of a particular skin color - the persecution of blackness - to look at the systemic structures of the same. In this way, one could include the discrimination of Asian labor immigrants in Latin America next to the subjection of blackness. Lee traces the spread of "yellow peril" speech and discourses of persecutions of Asians to the worldwide phenomenon of the project of modernity. She denounces its embedding in the necessity of establishing a hierarchy of ontological existence, as denounced as well by the concept of coloniality of being: "the worldwide spread of anti-Chinese sentiment during the second half of the nineteenth century demands that we understand the polycentric and global dimensions of racialized nationalisms" (ibidem:39).

Lee deconstructs the way Chinese and Japanese were represented and establishes parallelisms to how identities are subalternized for the sake of hegemonic national and international powers. Lee maps out the extent and nature of Orientalizing discourses in Brazil, which also included a sexual representation of these communities as deviant from the "hegemonic heteropatriarchal space" (ibidem: 76). These resources are equally employed to Black and Indigenous communities. She mentions, for instance, how in Rio Grande do Sul the word china is a synonym for prostitute, but it is commonly referred to when talking about indigenous sexual workers (ibidem: 146). The mixing together of these identities as a preferred Other, indistinctly repressed for the sake of power legitimation, can be identified within circumoceanism as a process also happening in East Asia. Instead of so-called coolie enslavement in the nineteenth century, however, we could refer to the same structures of representation when talking about Southeast Asian labor in China, Taiwan, Korea, or Japan; and Black, Latin-American, and other racialized groups in these same countries nowadays. 
We must be optimistic but also careful about the extents to which structurally repressive models like the modern nation-state can be re-adopted. As Lee explores, the relationship between racism and the project of modernity is not ascribed to a particular shade of skin color, but rather to the institutionalization of "foreign bodies" that can act as the oppositional example of the in-group. This logic cannot be fully attributed to the project of modernity, but it is within the paradigm of gendered coloniality that it can be inscribed as epistemological reality and common policy across the globe. It creates the paradox that just as racism and xenophobia against migrants from Asia have been essential elements in the establishment of modern Latin America, one can find racism and xenophobia against Latin-Americans serving the same function in Asia. This process of racialization and estrangement is at the same time related to a scale of perception of success within the system of coloniality. It is relevant to work within these terms when we study, for instance, the presence of Chinese institutions and industrial or mining businesses in the development of key national infrastructures in Latin America, the Middle East, and Africa. Do these actions subvert the perception of what the North is, or is this just another instance of innocuous changing of the contents without changing the form?

Lee (2018) closes her book framing it under the approach of Gilberto Freyre's bemusing conceptualization of Brazil as the place of the global South were many Orients converge and create a site of resistance. She navigates through the most controversial aspects of Freyre's oeuvre to settle on the concept of "unshadowing". This idea can be understood as another way of reaching coloniality of knowledge's critique: the need to unveil alternative epistemologies to the Western Enlightenment's monopolization of how we understand historical and contemporary reality. Lee weaves together these two notions, "unshadowing" and "circumoceanism" to reach the necessity of framing these processes beyond national, regional, mental, and material spaces. Her work is an inspiring example in the construction of a way of interpreting experiences from and across East Asia and Latin America with a decolonial and propositional aim of systemic disassembling.

Building on an encounter of epistemologies of the South creates new challenges on top of the ones already existing that are a consequence of its design and which need to be acknowledged. There is, for instance, the politics of language. Creating a transnational autonomous community of knowledge has been partially possible in Latin America because of the shared language of power that is Spanish and its closeness to Portuguese. Working in Spanish or Portuguese is already an arguably reasonable 
thorny aspect of concern, as it renders invisible the work produced to and from those Indigenous communities that do not wish to, or cannot use, this language necessarily associated with power groups and structures on the continent.

Added to the complexity of the situation, communities in East Asia have seen the need to resort to English as the safest bet to reach a broader intellectual and regional audience. Contrary to Spanish or Portuguese, English is not the language of many of their groups, either dominant or oppressed. While knowledge of each other's languages is not uncommon, it clearly cannot be assumed. Younghan Cho, for instance, mentions this as one of the main issues for Korean scholarship when establishing critical relationships with neighboring peers. It further heightens dependence upon Western theory, and Cho (2012: 660) laments, at the end of his article on the matter of colonial modernity in Korea, the fact that he must resort to English to share his concerns with other Asian scholars in non-Western communities. A true horizontal historiographical effort needs to combine therefore the empowerment of vernacular languages in any region - indigenous and otherwise - with the critical instrumentalization of instrumental languages. This paradoxical strategy echoes the same need of partially engaging with Western theory to subvert Western theory's position of authority.

The feeble position of Western-centric modes of knowing and doing within academia has been a longstanding concern, although unevenly distributed among not only territories, but also disciplines. In some instances, cries for its degradation, absence of purpose, and critical drawbacks have been present for decades. The question of the direction of so-called "area studies" in a post-Cold War era has been dragging on for thirty years. Created by Western powers as a means to gain knowledge over how to govern the non-Western world directly or indirectly, its raison d'être can only become more and more obsolete the more critically engaged communities outside and within the West grow to be. Gavin Walker and Naoki Sakai have recently pointed out that if area studies must survive, it needs to do so via a thorough and deeply committed restructuring of the concept of area and the academic institutions that support it:

what is in question for us is not "the end of area" as in the end of the importance of specific knowledge, linguistic study, or historically particular circumstances; the end of area means just the opposite, the end of the schema area, the end of the regime area, the end of this epistemic poietic device through which knowledge is "nationalized". (Walker and Sakai, 2019: 20) 
They defend, rather, a model of engaging with these studies that is based on what they call "civilizational transfer" (ibidem: 10). One of the main hindrances in the reconstruction of a more horizontal and fair "area" studies is the need to break with the uneven relationship between object and subject of study. This challenge is not unique to area studies but it has been particularly pernicious when it comes to the construction of oppressive epistemologies, as the Western gaze, as we have seen, engenders difference through distinctions of power. Shu-Mei Shih has pointed out, for instance, how the future must include a more open recognition of differences within particular in-groups rather than seeking difference in the other, the foreign, and the exoticized. Cultural globalization has strengthened an understanding of cultures as estranged and reified, in crisis with the idea of mutual exchange brought by internationalism (Shih, 2019: 38). Postcolonial and decolonial researchers and activists must then not only identify this bias but also fight against it by balancing our inward and outward attempts to scrutinize.

We must call upon converting epistemological diversity into an articulated strategy. With the combination of these ideas, this approach will tackle both the particular circumstances of each movement and erode the pillars of the system that maintains them. The aim is then to build a model that does not lead to the same - or, an equally important but sometimes overshadowed consequence - different types of oppression to these or other social groups.

\section{Conclusions}

By opting to explore the possibilities of expanding the idea of epistemologies of the South, this paper wishes to engage with a taunting but essential task. It highlights the relevance of democratizing concepts from postcolonial and decolonial theory by freeing them from their original author's imprints while honoring their contributions. Santos, Rivera Cusicanqui, Quijano, and other important household names have made a great impact on the way we relate to ideas of epistemic (in)justice, but we would do well not to lose sight of the collective and horizontal nature of this struggle. Their ideas must be taken up, inspected, criticized, and expanded upon when necessary to avoid falling into the traps of star-system dogmatism.

Similarly, I believe we must keep problematizing the task of shaping concrete methodologies based on particular experiences. Santos develops a very compelling and clearly systematized approach to decolonial methodologies around keywords like "abyssal line" and "sociology of absences". These concepts are useful in their expositional lucidity and because they stress the need to transform intellectual toil into concrete, 
directional, and communal action. It would be a mistake, however, to shape watertight frameworks of operations based on these or any other outcomes from decolonial theory. Decolonization is a constant struggle. There are always new horizons, and we must all be open to incorporating different voices from different realities with different approaches and understandings to the fight against material and epistemic oppressions. As Santos himself states (2018b: viii), the purpose of the epistemologies of the South is not to create an alternative epistemology, but to create an alternative to how we relate with alternative epistemologies.

This article has explored the range of possibilities and challenges in establishing a more systematic decolonial approach to the understanding of experiences in East Asia. It has advocated for the strengthening of a network of transfer and flow of knowledge across the global South. These exchanges share a common perception and denunciation of how the establishment of Western Eurocentric epistemologies, as the reigning paradigm through the project of modernity, is both the source and guarantee for the perpetuation of these circumstances of oppression. Although there have been voices to and from East Asia that have incorporated a decolonial or equivalent approach, I argue for the advantages of engaging with this framework in a more open and cross-disciplinary manner. Exploring these questions within this framework offers useful tools of exegesis. It also contributes to a better comprehension of these structures as a global phenomenon that requires methods of analysis and operations alternative to those that underpin epistemic and material oppressions. At the same time, however, they generate new tests and predicaments that need to be properly acknowledged and addressed while the work unfolds.

I would like to conclude this piece by stressing the essential relevance of having to articulate our thoughts and work to appeal and be in constant dialogue with people's movements. These theoretical considerations are helpless and even self-defeating if they are not designed in conjunction with the experience, expertise, and judgment of those social agents and actors that do day-to-day work against the direct effects of coloniality: that is, an open political position of anti-colonial activism. The struggle for decolonization is the fight against the top-down hierarchization of being, knowing, and doing as imposed by the hegemonic Western modern paradigm. Identifying points of conflict and naming solutions matters, but we must avoid turning their strength into a sterile school of analysis and always seek connections across experiences that come from different groups and fields of struggle: individual actions, local associations, objective-driven mobilizations, cultural exchange that happens outside 
of academia or institutionalized education, collective operations at a municipal, regional, national, and international level.

Edited by Scott M. Culp

\section{References}

Barlow, Tani (2012), "Debates over Colonial Modernity in East Asia and Another Alternative," Cultural Studies, 26(5), 617-644.

Bhambra, Gurminder K. (2014), Connected Sociologies. London: Bloomsbury Collections. Biko, Steve (1994), "White Racism and Black Consciousness", Democracy in Action, 8(6), 6-9.

Cho, Younghan (2012), "Colonial Modernity Matters?”, Cultural Studies, 26(5), 645-669.

Grosfoguel, Ramón (2006), "World-Systems Analysis in the Context of Transmodernity, Border Thinking, and Global Coloniality", Review (Fernand Braudel Center), 29(2), 167-187.

Jenco, Leigh Kathryn (2007), “'What Does Heaven Ever Say?' A Methods-Centered Approach to Cross-Cultural Engagement", The American Political Science Review, 101(4),741-755.

Kim, David Haekwon (2015), "José Mariátegui's East-South Decolonial Experiment”, Comparative and Continental Philosophy, 7(2), 157-179.

Lee, Ana Paulina (2018), Mandarin Brazil: Race, Representation, and Memory. Stanford, CA: Stanford University Press.

Lee, Hyunjung; Cho, Younghan (2012), "Introduction: Colonial Modernity and Beyond in East Asian Contexts”, Cultural Studies, 26(5), 601-616.

Lugones, María (2010), "Toward a Decolonial Feminism”, Hypathia, 25(4), 742-759. Matsuda, Hiroko (2018), Liminality of the Japanese Empire. Honolulu: University of Hawai'i Press.

Mignolo, Walter (2010), Desobediencia epistémica: retórica de la modernidad, lógica de la colonialidad y gramática de la descolonialidad. Buenos Aires: Ediciones del Signo.

Muñoz González, Yolanda (2008), La literatura de resistencia de las mujeres ainu. México, D. F.: El Colegio de México.

Nishiyama, Hidefumi (2015), "Towards a Global Genealogy of Biopolitics: Race, Colonialism, and Biometrics beyond Europe", Environment and Planning D: Society and Space, 33, 331-346.

Olivieri, Chiara (2016), China y el Islam: creación de identidades sinomusulmanas. Granada: Editorial Comares.

Qi, Xiaoying (2017), "Social Movements in China: Augmenting Mainstream Theory with Guanxi”, Sociology, 51(1), 111-126. 
Rivera Cusicanqui, Silvia (2012), "Ch'ixinakax utxiwa: A Reflection on the Practices and Discourses of Decolonization”, South Atlantic Quarterly, 111(1), 95-109. Translation by Brenda Baletti.

Rivera Cusicanqui, Silvia (2018), Un mundo ch'ixi es posible. Buenos Aires: Tinta Limón.

Santos, Boaventura de Sousa (2007), "Beyond Abyssal Thinking: From Global Lines to Ecologies of Knowledges", Review, 30(1), 45-89.

Santos, Boaventura de Sousa (2018a), "Introducción a las epistemologías del Sur", in Maria Paula Meneses; Karina Bidaseca (eds.), Epistemologías del Sur: epistemologias do Sul. Buenos Aires: CLACSO, 25-62.

Santos, Boaventura de Sousa (2018b), The End of the Cognitive Empire: The Coming of Age of Epistemologies of the South. Durham: Duke University Press.

Shih, Shu-Mei (2019), "Racializing Area Studies, Defetishizing China”, positions: asia critique, 27(1), 33-65.

Yoneyama, Lisa (2017), “Toward a Decolonial Genealogy of the Transpacific”, American Quarterly, 69(3), 471-482.

Walker, Gavin; Sakai, Naoki (2019), “The End of Area”, positions: asia critique, 27(1), 1-31.

Wang, Chih-Ming (2012), “Geopolitics of Literature”, Cultural Studies, 26(5), 740-764.

Received on 14.09.2019

Accepted for publication on 19.02.2021

\section{Jordi Serrano-Muñoz}

El Colegio de México, Centro de Estudios de Asia y África

Carretera Picacho Ajusco 20 Ampliación, Fuentes del Pedregal, 14110 Tlalpan, Ciudad de México,

México

Contact: jordi@serranomunoz.com

ORCID: https://orcid.org/0000-0001-5113-4314 


\section{Teoria descolonial na Ásia Oriental? Delineando um paradigma partilha- do das epistemologias do Sul}

Este artigo explora os desafios e as potencialidades de se estabelecer um paradigma partilhado de conhecimento transformador baseado no diálogo entre as experiências da Ásia Oriental e o resto do Sul global, particularmente a América Latina. O texto agrega e organiza uma visão geral das tentativas significativas de enquadrar as lutas da Ásia Oriental no seio de resistências contra as imposições epistemológicas e hegemónicas ocidentais. $\mathrm{O}$ artigo defende a procura de vínculos partilhados e diferenças críticas que podem ajudar a incorporar as experiências da Ásia Oriental dentro do paradigma das epistemologias do Sul. Este estudo também problematiza a articulação de uma metodologia proposicional de comparação que possa nutrir a produção de abordagens locais descoloniais e fomentar a partilha de práticas e saberes de e para a Ásia Oriental.

Palavras-chave: Ásia; colonialismo; descolonização epistemológica; Sul global; teoria do conhecimento.
La théorie décoloniale en Asie de l'Est? Décrivant un paradigme partagé des épistémologies du Sud

Dans cet article, on explore les défis et les potentialités de l'établissement d'un paradigme partagé de connaissances transformatrices basé sur le dialogue entre les expériences de l'Asie de l'Est et le reste du Sud mondial, en particulier l'Amérique latine. On rassemble et organise un aperçu général des tentatives significatives d'encadrer les luttes d'Asie de l'Est au sein des résistances contre les impositions épistémologiques hégémoniques occidentales. On défend la recherche de liens partagés et de différences critiques qui peuvent aider à intégrer les expériences de l'Asie de l'Est dans le paradigme des épistémologies du Sud. Dans cette étude, on problématise également l'articulation d'une méthodologie propositionnelle de comparaison qui pourrait nourrir la production d'approches locales et décoloniales et favoriser l'échange de pratiques et de connaissances depuis et vers l'Asie de l'Est.

Mots-clés: Asie; colonialisme; décolonisation épistémologique; Sud global; théorie de la connaissance. 
